Metal-Mediated Synthesis

\title{
Palladium-Catalyzed Oxidative Arylation of ortho-Phenylcarbamates with Arenes
}

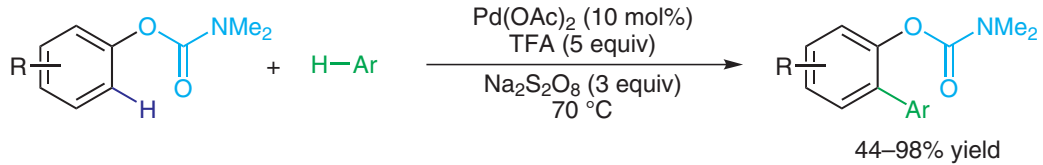

Selected examples:<smiles>CC(=O)Oc1c(C)cccc1-c1ccc(Cl)c(Cl)c1</smiles>

$80 \%$ yield<smiles>COC(=O)c1c(Cl)cccc1-c1ccccc1</smiles>

$73 \%$ yield<smiles>COc1cc(C)ccc1-c1ccc(Cl)c(Cl)c1</smiles>

$85 \%$ yield<smiles>COc1cc(F)ccc1-c1ccc(Cl)c(Cl)c1</smiles>

$84 \%$ yield<smiles>COc1cc(Cl)ccc1-c1ccc(Cl)c(Cl)c1</smiles>

$76 \%$ yield<smiles>COc1ccc(-c2ccc(C)c(C)c2)c(OC(C)=O)c1</smiles>

$76 \%$ yield<smiles>CCc1cccc(-c2ccc(F)c(F)c2)c1OC</smiles>

$69 \%$ yield<smiles>COc1ccc(-c2ccc(OC)c(OC)c2)c(OC(C)=O)c1</smiles>

$47 \%$ yield

Mechanistic proposal:

Proven by X-ray structure:
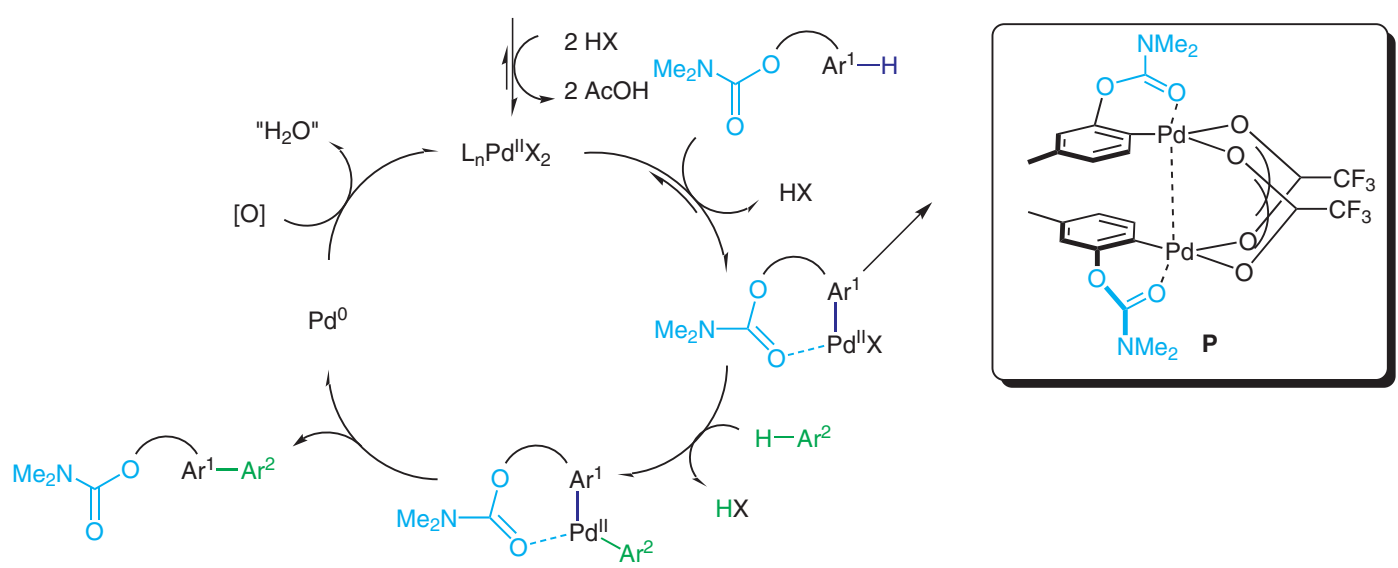

Significance: A highly useful method for the oxidative palladium-catalyzed coupling of simple arenes and ortho-phenylcarbamates was developed. The reaction proceeds via double $\mathrm{C}-\mathrm{H}$ bond functionalization with high regioselectivities including electron-rich, -neutral, and-deficient arenes as substrates.
Comment: This novel coupling method enables a most straightforward access to biaryls form simple arenes solely via $\mathrm{C}-\mathrm{H}$ functionalization. Inexpensive and environmentally benign sodium persulfate $\left(\mathrm{Na}_{2} \mathrm{~S}_{2} \mathrm{O}_{8}\right)$ is used as oxidant. The mechanism proposed for this reaction is supported by the X-ray structure of the palladacycle $\mathbf{P}$.

SYNFACTS Contributors: Paul Knochel, Tobias Thaler 